\title{
Elution of antibodies from biopsy tissue
}

T. E. W. FELTKAMP AND J. H. BOODE

From the Central Laboratory of the Netherlands Red Cross Blood Transfusion Service and Laboratory of Immunopathology, University of Amsterdam, Amsterdam

SYNOPSIS Cryostat sections proved to be sufficient material for acid elution of bound antibodies in vitro or in vivo. By single reconstitution of the $\mathrm{pH}$ the eluate may be studied for antibodies with the immunofluorescence technique. This micro-elution method may be of value for the study of kidney biopsy tissues.

Elution of antibodies from renal tissue became an important tool for the study of nephritis (Freedman and Markowitz, 1959; Koffler, Schur, and Kunkel, 1967; Lerner, Glassock, and Dixon, 1967). The eluted antibodies may be characterized by recombination with tissue antigens performing the immunofluorescence technique.

Most workers in this field used tissue homogenates as substrate for elution procedures. This is a disadvantage if only small biopsies are available for examination. To overcome this difficulty we propose the following method.

\section{Materials and Methods}

ELUTION OF BOUND ANTIBODIES in vitro Rat kidney was used as antigen for human antibodies against mitochondria, rat gastric mucosa for antibodies to smooth muscle and parietal cells, and human thyroid for anticolloid and antimicrosomal antibodies. Ten serial cryostat sections of $4 \mu$ thickness were mounted side by side on a glass slide. The kidney and gastric mucosa sections were acetone-fixed for $10 \mathrm{~min}$ and subsequently incubated for $30 \mathrm{~min}$ at room temperature with human sera containing the antibodies diluted 1:10. After washing for $30 \mathrm{~min}$ with phosphate-buffered saline (0.01 M phosphate, $p H$ 7.2) each group of 10 sections was surrounded by a ring of paraffin. The sections were Received for publication 10 December 1969. covered with $0.2 \mathrm{ml}$ of a $0.02 \mathrm{M}$ citrate buffer, pH $3 \cdot 2$, and incubated overnight in a humid atmosphere of $4^{\circ} \mathrm{C}$.

The citrate buffer, now called the eluate, is sucked up with a calibrated syringe in which the volume is determined, and put into a small test tube. A previously calculated amount of $0.4 \mathrm{M}$ $\mathrm{NaOH}$ is added to achieve a $p \mathrm{H}$ of about 7.2. The $p H$ is controlled using a two-in-one microelectrode and adjusted further by the addition of $0.1 \mathrm{M} \mathrm{HCl}$ or $0.4 \mathrm{M} \mathrm{NaOH}$. Without dialyzation or concentration the eluate is now given to new cryostat sections containing the appropriate antigens to determine the presence of antibodies with the indirect immunofluorescence technique, using a fluorescein isothiocyanate conjugated horse antihuman Ig reagent with the following characteristics: protein concentration $10.6 \mathrm{mg} /$ $\mathrm{ml}$; mean molecular $\mathrm{F} / \mathrm{P}$ ratio 2.8 (equal to an 'optical density ratio' $\left(\mathrm{E}^{\mathbf{1}}{ }_{495}: \mathrm{E}^{\mathbf{1}}{ }_{280}\right)$ of 0.7$)$ freed from proteins with $\mathrm{mol} F / P$ ratios $<1$ and $>4$; agar block titration titre against human IgG 1:2 (Feltkamp, 1969); final dilution used 1:45.

ELUTION OF BOUND ANTIBODIES in vivo Cryostat sections of kidney tissue from two female NZB/W mice, aged 7 and 9 months, and a female NZB mouse, aged 15 months, were eluted as described above. The eluate was recombined with the eluted renal sections and also studied for antinuclear antibodies on formalinized chicken red cell nuclei (ten Veen and Feltkamp, 1969) 
with the indirect immunofluorescence technique using a rabbit antimouse IgG serum (Hijmans, Radema, van Es, Feltkamp, van Loghem, and Schaap, 1969) and a horse antirabbit Ig conjugate (Schaap, Feltkamp, and Breebaart, 1969).

Besides elution from sections on slides the same method was also performed on sections in test tubes. For this purpose about 25 sections were sampled in a tube at $-20^{\circ} \mathrm{C}$. After the addi-

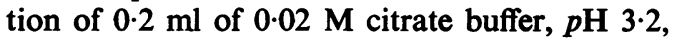
the tubes were sealed with parafilm and incubated overnight at $4^{\circ} \mathrm{C}$. The supernatant obtained after centrifugation for $15 \mathrm{~min}$ was further tested as described above.

\section{Results}

After reconstitution to $p \mathrm{H} \mathbf{7 \cdot 2}$ the eluates from the sections containing bound antibodies in vitro showed the expected patterns if tested with the indirect immunofluorescence technique on appropriate tissue sections. The intensity was only slightly weaker than the reaction obtained with the original 1:10 diluted antibody-containing sera. Negative results were obtained if phosphatebuffered saline was used instead of the acidcitrate buffer.

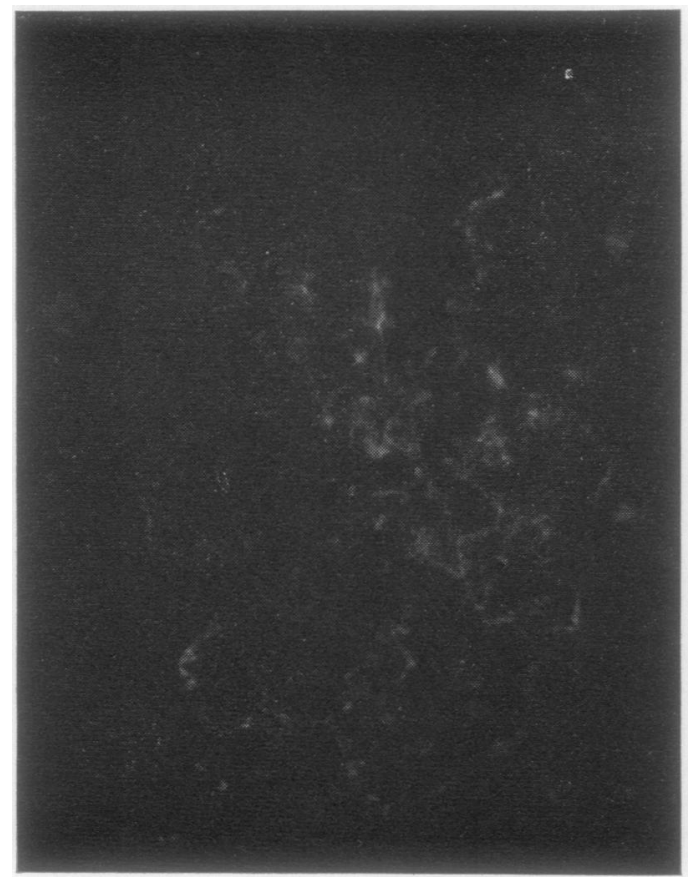

Fig. 1 Section of renal tissue from a NZB/W mouse after elution with citrate buffer (pH 3.2) and a subsequent incubation with a rabbit antimouse IgG serum and a fluorescein isothiocyanate conjugated horse antirabbit Ig reagent. Most of the mouse IgG is eluted by the acid elution. $\times 500$

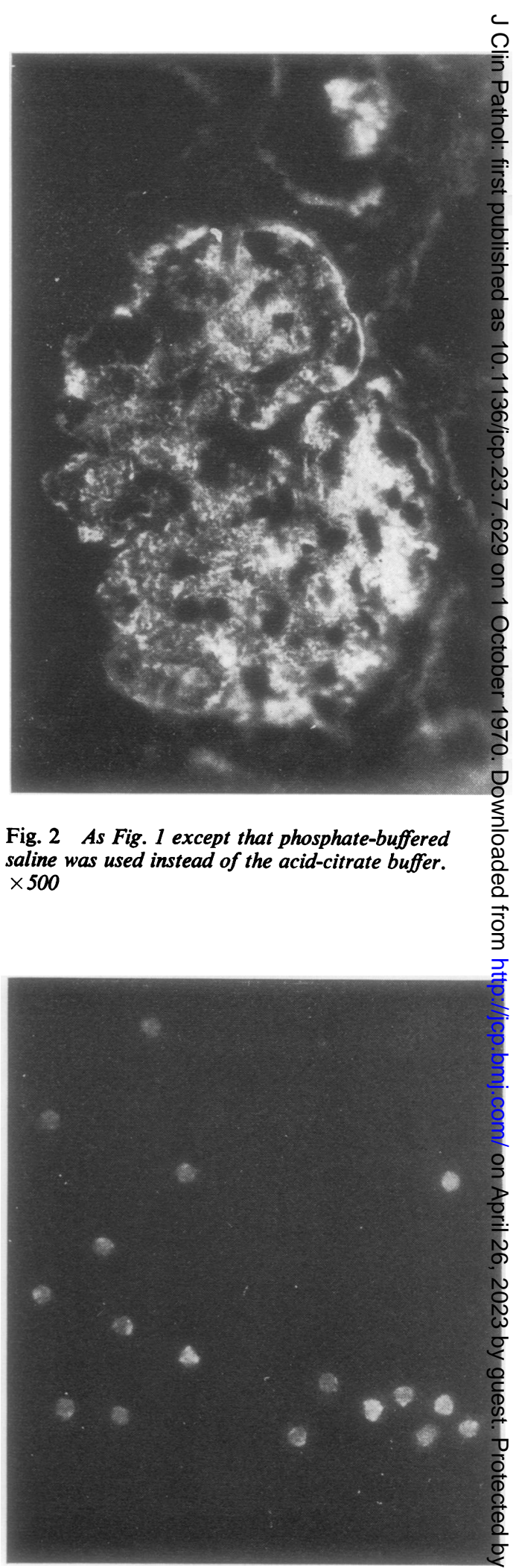

Fig. 3 Formalinized nuclei of chicken red cells incubated with the eluate of $N Z B / W$ kidney sections. The indirect immumofluorescence technique reveals the presence of antinuclear antibodies. $\times 500$ 
If the eluted sections were studied with the direct immunofluorescence technique for the presence of antibodies a negative result was obtained. If, however, phosphate-buffered saline was used instead of the acid-citrate buffer the expected fluorescent patterns were observed.

The acid eluates from renal sections of two NZB/W mice and one NZB mouse showed, after reconstitution to $p \mathrm{H} 7 \cdot 2$, the presence of antinuclear antibodies if studied on chicken red cell nuclei (Figs. 1, 2, and 3). Also, recombination with the eluted renal sections resulted in a nuclear fluorescence if studied with the indirect immunofluorescence technique. If, however, phosphate-buffered saline was used instead of the acid-citrate buffer a negative result was obtained.

The results obtained by elution of sections sampled in test tubes were better than those from elution of sections on slides. This is probably due to the increased tissue : elution-buffer ratio, resulting in a higher final antibody concentration.

\section{Discussion}

The micro-elution method presented is founded on experience obtained by elution from homogenized tissue material. Mellors (1965) has already described the use of cryostat sections for acidelution procedures. He dialysed the eluate against phosphate-buffered saline and performed a final concentration. In our hands this procedure resulted in a loss of antibody activity if compared with the method described in the present study.

The presented micro-elution method proved to be of value for the study of human renal biopsy material, as will be mentioned in future communications.

\section{References}

Feltkamp, T. E. W. (1970). In Standardization in Immunofluorescence, a Symposium, edited by E. J. Holborow, W. D. Brighton, G. Sander and C. E. D. Taylor, p. 189. Blackwell Scientific Publications, Oxford, in press.

Freedman, P., and Markowitz, A. S. (1959). Immunological studies in nephritis. Lancet, 2, 45-46.

Hijmans, W., Radema, H., van Es, L., Feltkamp, T. E. W., van Loghem, J. J., and Schaap, O. L. (1969). Cryoglobulins in iv New Zealand black mice. Clin. exp. Immunol., 4, 227-239. $\omega$

Koffler, D., Schur, P. H., and Kunkel, H. G. (1967). Immuno - V logical studies concerning the nephritis of systemic lupus is erythematosus. J. exp. Med., 126, 607-623.

Lerner, R. A., Glassock, R. J., and Dixon, F. J. (1967). The role of anti-glomerular basement membrane antibody in the pathogenesis of human glomerulonephritis. J. exp. Med., 126, 989-1004.

Mellors, R. C. (1965). Autoimmune disease in NZB/B1 mice. 1. Pathology and pathogenesis of a model system of spontaneous glomerulonephritis. J. exp. Med., 122, 25-40.

Schaap, O. L., Feltkamp, T. E. W., and Breebaart, A. C. (1969). $\mathbb{D}$ Circulating antibodies to corneal tissue in a patient suffering from Mooren's ulcer (ulcus rodens corneae). Clin. exp. Immunol., 5, 365-370.

ten Veen, J. H., and Feltkamp, T. E. W. (1969). Formalinized chicken red cell nuclei as a simple antigen for standardized antinuclear factor determination. Clin. exp. Immunol., 5, 673-678. 